See discussions, stats, and author profiles for this publication at: https://www.researchgate.net/publication/323640213

\title{
Towards a smart systems view of museum networks
}

Conference Paper · January 2017

CITATIONS

0

4 authors, including:

Francesco Caputo

Università degli Studi di Salerno

99 PUBLICATIONS 910 CITATIONS

SEE PROFILE

Biagio Merola

Università degli studi di Foggia

10 PUBLICATIONS 82 CITATIONS

SEE PROFILE

Some of the authors of this publication are also working on these related projects:

Emerald Gender in Management, vol32, iss.3 March the 27th, 2017 View project

Co-creation in Healthcare! View project
READS

29

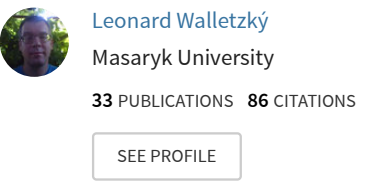




\section{Towards a smart systems view of museum networks}

Caputo Francesco (Corresponding Author)

Masaryk University, Czech Republic.

Montella Marta Maria

La Sapienza University of Rome, Italy.

Walletzky Leonard

Masaryk University, Czech Republic.

Merola Biagio

University of Foggia, Italy.

\section{Abstract}

\section{Aim}

The domain of cultural heritage management includes the complex of activities planned and implemented with the aim to define more efficient, effective, and sustainable approaches in the management of products, services, and traditions that have a high-value for a specific culture (Stovel, 1998; Cameron \& Kenderdine, 2007; Montella, 2010a, 2011; Cerquetti, 2011).

Along the time, different research streams have focused the attention on the opportunity to define new pathways and perspectives in the management of cultural heritage as way to increase its positive effects on the social and economic development of territories (Bessière, 1998; Scott, 2004; Hampton, 2005; Cerquetti, 2010).

In such a line, many contributions have been offered with reference to the implementation of more efficient communication strategies (Kalay et al., 2007), to the development of more appealing experiences (Otnes \& Maclaran, 2007; Pietroni, 2012), and to the adoption of technology based innovations to increase the attractiveness of cultural heritage (Meyer et al., 2007; Ott \& Pozzi, 2011).

Despite the relevance of all these contributions, it is possible to underline the existence of a dominant object-based approach in which the cultural heritage is viewed as a sort of 'good to sell' by acting on the traditional marketing levers (Barile et al., 2012; Barile \& Saviano, 2014). Conversely, little attention is paid with reference to the opportunities related to a 
radical change in perspective in the way in which the cultural heritage is perceived (Inglehart, 1990; Kreps, 2003; Barile, 2012).

In order to bridge this gap, the paper builds upon the conceptual and interpretative framework offered by the Systems Thinking (Beer, 1979; Espejo, 1990, 1994; Espejo \& Reyes, 2011; Barile \& Saviano, 2010, 2011; Golinelli, 2010; Barile et al., 2012, 2016) and the Self-Organization Theory (Witt, 1997; Foster \& Metcalfe, 2003; Ulrich \& Probst, 2012) in order to identify possible approaches that can support the widening of perspective in the management of cultural heritage.

More specifically, by shifting the focus from the management of cultural heritage items to the management of cultural heritage systems, the paper focuses the attention on the topic of museum networks (Lorenzoni, 1987; Crooke, 2006; Pencarelli \& Splendiani, 2011). In such a line, the work investigates the conditions required for the emergence and survival of museum networks in order to highlight the possible contribution of Information and Communication Technologies (ICTs) in defining more performant managerial models by acting on collaboration, information sharing, and communication (Ing, 1999; Lemelin \& Bencze, 2004; Marty \& Jones, 2008).

To this aim, the work adopts the interpretative lens of the Viable Systems Approach (VSA) (Barile, 2009a; Golinelli, 2010; Barile et al., 2014) in order to 'observe' museum networks as viable systems (Barile, 2009b) in terms of systems able to survive in their contexts by establishing effective relationships with their relevant suprasystems.

\section{Research pathway}

By adopting the interpretative contributions offered by the System Thinking, the paper proposes a literature review on the topic of cultural heritage management in order to: 1) define criteria and guidelines for an effective systems management of museum networks (Albert et al., 2005; Van Huy, 2006; Cerquetti \& Montella, 2015); 2) develop a framework of reference useful to investigate the museum network as a viable system (Barile, 2013; Barile et al., 2014; Saviano \& Caputo, 2013); and 3) underline the advantages related to the network configuration in the cultural heritage management (Thorelli, 1986; Lorenzoni, 1992; Latin, 1991; Polese, 2004).

The theoretical reflections herein are verified using a qualitative method approach (Gubrium \& Holstein, 1997) based on the analysis of a single case study (Flyvbjerg, 2006): the Sistema Museale Regionale dell'Umbria. The empirical observation is direct to investigate what are the elements able to affect the emergence of a viable system from the management of museum network. Moreover, a technology-based view is adopted in order to define possible contributions of ICT in improving network museums' ability to dynamically adapt theirself to the changes of 'markets' through a more efficient, effective, and sustainable approach to the management of variety (Dickover, 1994; Montella, 2010b; de Oliveira \& da Silva, 2011; Espejo \& Reyes, 2011). 


\section{Theoretical and practical implications}

The interpretative framework herein supports a better understanding of the variety that affects the interactions among the various actors that are involved in the articulated scenario of cultural heritage (Barile \& Saviano, 2012; Golinelli, 2012) and of the opportunities offered by the ICTs in ensuring a smart approach in the management of cultural heritage (Frattasi et al., 2006; Duff et al., 2010).

In the same direction, the paper offers useful indications to decision makers interested in adopting an innovative approach to the management of museum networks able to overcome the limitations of traditional transactional view (Gouthier \& Schmid, 2003; Van de Werfhorst \& Hofstede, 2007).

\section{Conclusions and future directions for research}

In a context like Italy in which the social and economic development of a territory can significantly rely on cultural heritage, the development of adequate managerial approaches for museum is acquiring an increasing relevance. In this direction, the paper highlights the contribution of systems thinking to the management of museum networks by underlining the relevant opportunities offered by a smart approach to ICT in improving collaboration, information sharing, and communication between different cultural heritage units in the building of shared pathways to address the challenges of increasing market variety.

\section{Keywords}

Cultural Heritage Management; Museum Networks; Systems Thinking; Smart Technologies; Management of variety.

\section{References}

Barile, S. (2009a). Management Sistemico Vitale. Giappichelli, Torino.

Barile, S. (2009b, July). The dynamic of informative varieties in the processes of decision making. In The 3rd International Conference on Knowledge Generation, Communication and Management. Orlando, Florida.

Barile, S., \& Saviano, M. (2010). A new perspective of systems complexity in service science. Impresa, Ambiente, Management, 4(3), 375-414.

Barile, S. (2012). Verso una novata ipotesi di rappresentazione del concetto di bene culturale. In Golinelli G.M. (eds), Patrimonio culturale e creazione di valore. Verso nuovi percorsi (pp. 71-96), Cedam, Padova.

Barile, S. (Ed.) (2013). Contributions to Theoretical and Practical Advances in Management. A Viable Systems Approach (VSA), Vol. II. Aracne, Roma. 
Barile, S., Lusch, R., Reynoso, J., Saviano, M., \& Spohrer, J. (2016). Systems, networks, and ecosystems in service research. Journal of Service Management, 27(4), 652-674.

Barile, S., Montella, M., \& Saviano, M. (2012). A service-based systems view of cultural heritage. Journal of Business Market Management, 5(2), 106-136.

Barile, S., Pels, J., Polese, F., \& Saviano, M. (2012). An introduction to the viable systems approach and its contribution to marketing. Journal of Business Market Management, 5(2), 54-78.

Barile, S., Pels, J., Polese, F., Saviano, M. (2012). An Introduction on the Viable Systems Approach and its contribution to Marketing. Journal of Business Market Management, 2, 54-78.

Barile, S., \& Saviano, M. (2011). Foundations of systems thinking: the structure-system paradigm. In Vv. Aa., Contributions to Theoretical and Practical Advances in Management. A Viable Systems Approach (VSA) (pp. 1-24). International Printing, Avellino.

Barile, S., \& Saviano, M. (2012). Dalla Gestione del Patrimonio di Beni Culturali al Governo del Sistema dei Beni Culturali. In G.M. Golinelli (Ed.), Patrimonio culturale e creazione di valore, Verso nuovi percorsi (pp. 97-148), Cedam, Padova.

Barile, S., \& Saviano, M. (2014). Resource Integration and Value Co-Creation in Cultural Heritage Management. In Aiello L. (Ed.), Handbook of Research on Management of Cultural Products: E-Relationship Marketing and Accessibility Perspectives (pp. 5882). Business Science Reference, Hershey, PA.

Barile, S., Saviano, M., \& Caputo, F. (2014). A systems view of customer satisfaction. In National Conference "Excellence in quality, statistical quality control and customer satisfaction”, University Campus “Luigi Einaudi”, University of Turin, September 1819.

Beer, S. (1979). The heart of enterprise. John Wiley \& Sons, New York.

Bessière, J. (1998). Local development and heritage: traditional food and cuisine as tourist attractions in rural areas. Sociologia ruralis, 38(1), 21-34.

Cameron, F., \& Kenderdine, S. (2007). Theorizing digital cultural heritage: A critical discourse. Mit Press, Cambridge, Massachusetts.

Cerquetti, M. (2010). Dall'economia della cultura al management per il patrimonio culturale: presupposti di lavoro e ricerca. Il capitale culturale. Studies on the Value of Cultural Heritage, 1, 23-46.

Cerquetti, M. (2011). L'innovazione del prodotto culturale. Economia, cultura, territorio, 55-69.

Cerquetti, M., \& Montela, M. M. (2015). Museum Networks and Sustainable Tourism Management. The Case Study of Marche Region's Museums (Italy). Enlightening Tourism. A Pathmaking Journal, 5(1), 100-125.

Crooke, E. (2006). Museums and community. A companion to museum studies, 171-185. 
de Oliveira, J.A., da Silva, A.J. (2011). Arts, Culture and Science and Their Relationships. Systemic Practice and Action Research, 24(6), 565-574

Dickover, N. (1994), Reflection-in-Action: Modelling a specific organization through the Viable Systems Model. Systems practice, 7(1), 43-62.

Duff, W. M., Carter, J., Howarth, L., Ross, S., \& Dallas, C. (2010). The museum environment in transition: the impact of technology on museum work. Cultural heritage on line, 1000-1005.

Espejo, R. (1990). The viable system model. Systemic Practice and Action Research, 3(3), 219-221.

Espejo, R. (1994). What is systemic thinking?. System Dynamics Review, 10(2-3), 199-212.

Espejo, R., \& Reyes, A. (2011). Organizational systems: Managing complexity with the viable system model. Springer Science \& Business Media, New York.

Espejo, R., \& Reyes, A. (2011). Organizational Systems: Managing Complexity with the Viable System Model. Heidelberg, Springer, New York.

Flyvbjerg, B. (2006). Five misunderstandings about case-study research. Qualitative inquiry, 12(2), 219-245.

Foster, J., \& Metcalfe, J.S. (Eds.) (2003). Frontiers of evolutionary economics: competition, self-organization, and innovation policy. Edward Elgar Publishing, London.

Frattasi, S., Fathi, H., Fitzek, F. H., Prasad, R., \& Katz, M. D. (2006). Defining 4G technology from the users perspective. IEEE network, 20(1), 35-41.

Golinelli, G.M. (2010). Viable Systems Approach. Governing Business dynamics. Cedam, Kluwer.

Golinelli, G.M. (Ed.) (2012), Patrimonio culturale e creazione di valore, Verso nuovi percorsi. Cedam, Padova.

Gouthier, M., \& Schmid, S. (2003). Customers and customer relationships in service firms: the perspective of the resource-based view. Marketing Theory, 3(1), 119-143.

Gubrium, J. F., \& Holstein, J. A. (1997). The new language of qualitative method. Oxford University Press on Demand.

Hampton, M. P. (2005). Heritage, local communities and economic development. Annals of tourism Research, 32(3), 735-759.

Ing, D. S. (1999). Innovations in a technology museum. IEEE Micro, 19(6), 44-52.

Inglehart, R. (1990). Culture shift in advanced industrial society. Princeton University Press.

Kalay, Y., Kvan, T., \& Affleck, J. (Eds.). (2007). New heritage: New media and cultural heritage. Routledge, London.

Kreps, C. F. (2003). Liberating culture: cross-cultural perspectives on museums, curation, and heritage preservation. Psychology Press, London.

Latin, R.V. (1991). Cybernetics and network management (viable system modeling). Systems practice, 4(4), 339-360. 
Lemelin, N., \& Bencze, L. (2004). Reflection-on-action at a science and technology museum: Findings from a university-museum partnership. Canadian Journal of Math, Science \& Technology Education, 4(4), 467-481.

Lorenzoni G. (1987). Costellazione di imprese e processi di sviluppo. Sviluppo $e$ Organizzazione, 102, 59-72.

Lorenzoni, G. (Ed.) (1992). Accordi, reti e vantaggio competitivo. Le innovazioni nell'economia d'impresa e negli assetti organizzativi. Etas Libri, Milano.

Marty, P. F., \& Jones, K. B. (2008). Museum informatics: People, information, and technology in museums. Taylor \& Francis, London.

Meyer, É., Grussenmeyer, P., Perrin, J. P., Durand, A., \& Drap, P. (2007). A web information system for the management and the dissemination of Cultural Heritage data. Journal of Cultural Heritage, 8(4), 396-411.

Montella, M. (2010a). Le scienze aziendali per la valorizzazione del capitale culturale storico. Il capitale culturale. Studies on the Value of Cultural Heritage, 1(1), 11-22.

Montella, M. (2010b). Arte, comunicazione, valore: una conversazione. Il capitale culturale. Studies on the Value of Cultural Heritage, 1(1), 149-161.

Montella, M. (2011). Conoscenza e informazione del cultural heritage come spazio d'impresa. Sinergie rivista di studi e ricerche, 76, 91-111.

Otnes, C.C., \& Maclaran, P. (2007). The consumption of cultural heritage among a British Royal Family brand tribe. Consumer tribes, 51-66.

Ott, M., \& Pozzi, F. (2011). Towards a new era for Cultural Heritage Education: Discussing the role of ICT. Computers in Human Behavior, 27(4), 1365-1371.

Pencarelli, T., \& Splendiani, S. (2011). Le reti museali come "sistemi" capaci di generare valore: verso un approccio manageriale e di marketing. Il capitale culturale. Studies on the Value of Cultural Heritage, (2), 227-252.

Pietroni, E., Ray, C., Rufa, C., Pletinckx, D., \& Van Kampen, I. (2012, September). Natural interaction in VR environments for Cultural Heritage and its impact inside museums: The Etruscanning project. In Virtual Systems and Multimedia (VSMM), 2012 18th International Conference on (pp. 339-346). IEEE.

Polese, F. (2004). L'integrazione sistemica degli aggregati reticolari di impresa. Cedam, Padova.

Ronald, C. (1937). The Nature of the Firm. Economica, 4(16), 386-405.

Saviano, M. \& Caputo, F. (2013). Managerial Choices between Systems, Knowledge and Viability. In S. Barile (Ed.), Contributions to Theoretical and Practical Advances in Management. A Viable Systems Approach (VSA) (pp. 219-242), Vol. II. Aracne, Roma.

Scott, A.J. (2004). Cultural-products industries and urban economic development prospects for growth and market contestation in global context. Urban affairs review, 39(4), 461490. 
Stovel, H. (1998). Risk preparedness: a management manual for world cultural heritage. ICCROM.

Thorelli, H.B. (1986). Networks: between Market and Hierarchies. Strategic management Journal, 7(1), 37-51.

Ulrich, H., \& Probst, G. (eds.) (2012). Self-organization and management of social systems: Insights, promises, doubts, and questions. Springer Science \& Business Media, New York.

Van de Werfhorst, H.G., \& Hofstede, S. (2007). Cultural capital or relative risk aversion? Two mechanisms for educational inequality compared. The British journal of sociology, 58(3), 391-415.

Van Huy, N. (2006). The role of museums in the preservation of living heritage: experiences of the Vietnam Museum of Ethnology. International Journal of Intangible Heritage, 1, 35-41.

Witt, U. (1997). Self-organization and economics - what is new?. Structural change and economic dynamics, 8(4), 489-507.

\section{About the Authors}

Francesco Caputo, Ph.D., is Post-Doctoral Researcher at Department of Computer Systems and Communications, Masaryk University, Czech Republic where he is lecturer of Service and System Thinking and of Knowledge Management. He is also adjunct Professor of Knowledge Management at Department of Informatics, University of Bari, Italy and member of Scientific Board of Reald Summer School (University of Reald Vlore Albania). His main research interests include but are not limited to complexity, knowledge management, healthcare management, network theory, corporate communication, strategy, and systems thinking. He is member of the Editorial Boards of different international journals and he serves as reviewer for many relevant journals. He is Secretariat of the ASVSA, Association for research on Viable Systems (www.asvsa.org). He was also finalist at the 2012/2013 Emerald/EMRBI Business Research Award and he has won the best presentation award at the 2016 B.S. Lab. Symposium "Governing Business Systems. Theories and Challenges for Systems Thinking in Practice".

Marta Maria Montella has a double disciplinary training. After graduating in Modern Art History, achieved in 2004 with honors from the University of Perugia, acquired qualifications relating to economics and management of enterprises and public organizations in the cultural sector.

Since 2010 she has $\mathrm{PhD}$ in Economics and Finance in the Company's Government. From 2011 to 2015 was research fellow of Economy and Business Administration at the University of Rome La Sapienza.

Since July 2016 she is Research Associate at the CNR-IRISS.

Her research is in the field of cultural heritage management (in museums and widespread on the territory) and cultural tourism, with particular attention to destination management. 
She completed studies and training activities in Italy and abroad, and held classes in Masters and undergraduate courses. She has participated as a speaker at national and international conferences. She has collaborated on scientific research projects and cooperated with private and public companies. As an author or co-author has published about 25 scientific papers in Italian and foreign books and magazines.

Leonard Walletzký is Assitant Professor in Service Science, Management and Engineering at the Faculty of Informatics of the Masaryk University, Czech Republic. His main research interests are: Service Science, Management and Engineering.

Biagio Merola is graduate in Business Administration at the University of Salerno, has participated Erasmus Programme at the University of Manchester and received the PhD in Business Administration at the University of Cassino. He is Assistant Professor of Business Management and Assistant Professor of Corporate Governance in the University of Foggia. He has participated in many conferences and has published articles in different journals. His research interests are: Health Management; Systemic Approach; Human Resources Management. 